\title{
The Level of Public Acceptance to the Development of a Coastal Flooding Early Warning System in Jakarta
}

\author{
Nelly Florida Riama ${ }^{1, *}$, Riri Fitri Sari ${ }^{2}$, Henita Rahmayanti ${ }^{3}\left(\mathbb{D}\right.$, Widada Sulistya ${ }^{4}$ \\ and Mohamad Husein Nurrahmat ${ }^{4}$ \\ 1 School of Environmental, Universitas Indonesia, Jakarta 10430, Indonesia \\ 2 Faculty of Engineering, Universitas Indonesia, Depok 16424, Indonesia; riri@ui.ac.id \\ 3 Faculty of Engineering, Jakarta State University, Jakarta 13220, Indonesia; henita.rahmayanti@unj.ac.id \\ 4 Agency for Meteorology, Climatology, and Geophysics, Kemayoran, Jakarta Pusat 10720, Indonesia; \\ widada.sulistya@bmkg.go.id (W.S.); huseinnurrahmat@gmail.com (M.H.N.) \\ * Correspondence: nelly.florida@ui.ac.id
}

Citation: Riama, N.F.; Sari, R.F.; Rahmayanti, H.; Sulistya, W.; Nurrahmat, M.H. The Level of Public Acceptance to the Development of a Coastal Flooding Early Warning System in Jakarta. Sustainability 2021, 13, 566. https://doi.org/10.3390/ su13020566

Received: 24 November 2020

Accepted: 6 January 2021

Published: 8 January 2021

Publisher's Note: MDPI stays neutral with regard to jurisdictional clai$\mathrm{ms}$ in published maps and institutional affiliations.

Copyright: () 2021 by the authors. Licensee MDPI, Basel, Switzerland. This article is an open access article distributed under the terms and conditions of the Creative Commons Attribution (CC BY) license (https:// creativecommons.org/licenses/by/ $4.0 /)$.

\begin{abstract}
Coastal flooding is a natural disaster that often occurs in coastal areas. Jakarta is an example of a location that is highly vulnerable to coastal flooding. Coastal flooding can result in economic and human life losses. Thus, there is a need for a coastal flooding early warning system in vulnerable locations to reduce the threat to the community and strengthen its resilience to coastal flooding disasters. This study aimed to measure the level of public acceptance toward the development of a coastal flooding early warning system of people who live in a coastal region in Jakarta. This knowledge is essential to ensure that the early warning system can be implemented successfully. A survey was conducted by distributing questionnaires to people in the coastal areas of Jakarta. The questionnaire results were analyzed using cross-tabulation and path analysis based on the variables of knowledge, perceptions, and community attitudes towards the development of a coastal flooding early warning system. The survey result shows that the level of public acceptance is excellent, as proven by the average score of the respondents' attitude by 4.15 in agreeing with the establishment of an early warning system to manage coastal flooding. Thus, path analysis shows that knowledge and perception have a weak relationship with community attitudes when responding to the coastal flooding early warning model. The results show that only $23 \%$ of the community's responses toward the coastal flooding early warning model can be explained by the community's knowledge and perceptions. This research is expected to be useful in implementing a coastal flooding early warning system by considering the level of public acceptance.
\end{abstract}

Keywords: coastal flood; early warning system; path analysis; public acceptance

\section{Introduction}

Coastal flooding is one of the natural disasters that often occur in coastal areas. The main causes of coastal flooding are tsunami, storm waves, inland flooding, and shallow coastal flooding [1]. Floods that occur on the coast are one of the major natural disasters that cause economic loss and loss of human life [2]. Coastal flooding is caused by various natural factors that build on each other to increase the impact on the people living in coastal areas. The extent of the coastal flooding is worse if it is accompanied by land subsidence in coastal areas. Land subsidence, combined with sea level rise, heavy rains, storms, and flood runoff from rivers, will expand the areas that are vulnerable to coastal flooding, particularly in Indonesian coastal cities [3]. This may result in extremely challenging problems in the management of islands and the provision of information related to marine affairs for coastal communities [4].

Jakarta, the capital city of Indonesia, is a large city in Southeast Asia that is highly vulnerable to coastal flooding. The province of the Special Capital Region of Jakarta (local term: Daerah Khusus Ibukota Jakarta (DKI Jakarta)) includes 13 natural and artificial rivers 
flowing through it, and $40 \%$ of its land is below the high tide mark [5]. The DKI Jakarta frequently experiences floods, which cause significant economic damage. The major floods that occurred in 2002, 2007, 2013, and 2014 have caused direct and indirect economic losses of billions of U.S. dollars [6-8].

It is urgently necessary to develop an early warning system to mitigate the casualties and infrastructure damage caused by coastal flooding [9]. For this reason, an early warning system model should be developed that can be disseminated to the community so that damage due to coastal flooding disasters can be mitigated. Therefore, there is a need for an early warning system of coastal flooding in Jakarta. It is hoped to improve communications of early warnings to the end-user [10]. An early warning system alone does not prevent hazards from turning into disasters. The need for early action is essential to mitigate potential damage [11]. Translating flood early warnings into a rapid, responsive action by every individual at risk of a flood disaster and in all the flood-affected areas requires coordinated and collaborative action from all the actors and stakeholders of early warning at all levels [12]. This early action will save thousands of lives and livelihoods, reduce vulnerability, and strengthen resilience.

A challenge with implementing an early warning system for the public is how they will accept the information and adapt to it in their daily life. A successful early warning system must have a people-centered approach (centered on community empowerment). Thus, an early warning system should be based on the community's approach and can protect the community [13]. Therefore, as part of the development of the coastal early warning system in this study, we aimed to measure public acceptance. The measurement of public acceptance must be performed before executing an early warning system to ensure the success of the early warning system before it is executed operationally.

The public behavior during flood situations is determined by their preparedness, and it is heavily influenced by many behavioral traits such as perceived benefits, risk awareness, or even denial [14]. The implementation of the new early warning system may trigger the emergence of a new problem regarding how the public understands the information provided and how they act on the information. Furthermore, the level of public acceptance of the coastal flooding early warning system needs to be analyzed. Consequently, the community can then receive and understand the information in a timely and accurate manner as a component of the early warning system in accordance with the main principles, i.e., accurate, timely, and reliably [15].

This research focused on how the public will respond to a coastal flooding early warning system by measuring public acceptance. The feedback from the community about the coastal flooding early warning system can improve the system to be an excellent service. This community involvement should be routine work to make warning messages understandable and have responses from the end-users [16].

The development of the early warning system will be described in another paper. We aimed to determine the level of public acceptance of an early warning system used for coastal flooding disaster mitigation. The level of public acceptance can be investigated by descriptively and inferentially analyzing questionnaire results using path analysis. The variables considered to be influential were knowledge, perceptions, and attitudes of the community [17].

The knowledge possessed by the community can be defined as experiential knowledge, which is repeatedly experienced in the realm of individuals in certain spatial, temporal, and social situations [18]. The accumulation of knowledge and life experiences of the people affected by the flooding will form a community adaptation plan to modify their behavior to adapt to the environment. Furthermore, they will consciously use that knowledge to determine current and future types of adaptations to flooding. The system's ability to modify or change their natural characteristics or behavior is a form of adaptation by the community [19]. Research has shown that when people feel the risk of an unacceptable event, they will engage in behavior that they believe is most appropriate and will produce the best results to minimize risk [20]. 
According to Mulyana [21], differences in ideology can lead to differences in thoughts, views, or concepts about human relationships and human perceptions of their reality. Accordingly, perception plays an important role in determining the community's attitudes in dealing with coastal flooding disasters. People respond to the danger they feel, and if their perception is wrong, then self-protection efforts, the public, and the environment will also tend to be wrong [22]. Several factors that can influence the disaster risk perception have been identified. One of them is that personal experience has a strong impact on the disaster risk perception, and makes people think more about the risks they might receive [23]. There are previous studies that discussed risk perception in responding to the behavior of early warning systems [24-26]. Risk perception is regarded as an assessment of the perceived probability of hazard and the perceived probability of the results (most often-negative consequences) $[27,28]$.

Kaiser [29] stated that, traditionally, the object of a person's environmental attitude is the natural environment (e.g., air quality), or focusing on conservative behavior such as recycling. In general, attitudes toward individual behavior refer to studies on the theory of planned behavior. Attitudes toward the environment are generally associated with a multiple component approach in which aspects of individual attitudes can be distinguished. The concept of environmental attitudes as a behavior used by individuals to apply this belief implies a strong relationship between individual attitudes and behaviors. The implication of these individual attitudes in this study can significantly affect individual behavior, which is then expanded into community behavior in handling coastal flooding on Jakarta's north coast.

\section{Material and Methods}

\subsection{Study Area}

The study was undertaken in North Jakarta, as it is an area that is very vulnerable to coastal flooding due to its location, which is directly adjacent to the sea and has experienced significant land subsidence over the past few years. In addition, the government is also developing a coastal flooding early warning system to reduce losses by implementing appropriate disaster mitigation in coastal areas. Therefore, it is very practical to choose North Jakarta as a research area. This study is one part of the proposed Coastal Flooding Early Warning model in Jakarta City.

Astronomically, DKI Jakarta Province is located between $6^{\circ} 12^{\prime} \mathrm{S}$ latitude and $106^{\circ} 48^{\prime} \mathrm{E}$ longitude. The demographic details of the study are shown in Figure 1. DKI Jakarta Province is a lowland with an average height of $\pm 7 \mathrm{~m}$ above sea level. DKI Jakarta Province is bordered by the coast from west to east along $\pm 35 \mathrm{~km}$ to the north based on its geographical position. The coastal area is the place for 13 rivers that borders the Java Sea. Meanwhile, in the west, it is bordered by Banten Province and West Java Province on the south and east. In this study, the focus of the research area is on the north coast of Jakarta, which administratively belongs to the Municipality of North Jakarta. The area of North Jakarta itself is $146.66 \mathrm{~km}^{2}$. North Jakarta stretches from West to East along approximately $35 \mathrm{~km}$, jutting inland between 4 and $10 \mathrm{~km}$. The height from sea level is between 0 and $2 \mathrm{~m}$, while it is below sea level in certain places. Administratively, North Jakarta consists of 6 sub-districts, namely: Penjaringan, Pademangan, Tanjung Priok, Koja, Kelapa Gading, and Cilincing districts, each with an area of $45.41 \mathrm{~km}^{2}, 11.92 \mathrm{~km}^{2}, 22.52 \mathrm{~km}^{2}, 12.25 \mathrm{~km}^{2}$, $14.87 \mathrm{~km}^{2}$, and $39.70 \mathrm{~km}^{2}$.

As previously explained, Jakarta has an overly complex condition if we examine coastal causes of flooding that often occur in this area. In addition, the level of public acceptance of the coastal flooding early warning system is needed to mitigate coastal flooding disasters so that the economic and social impacts can be significantly reduced. 


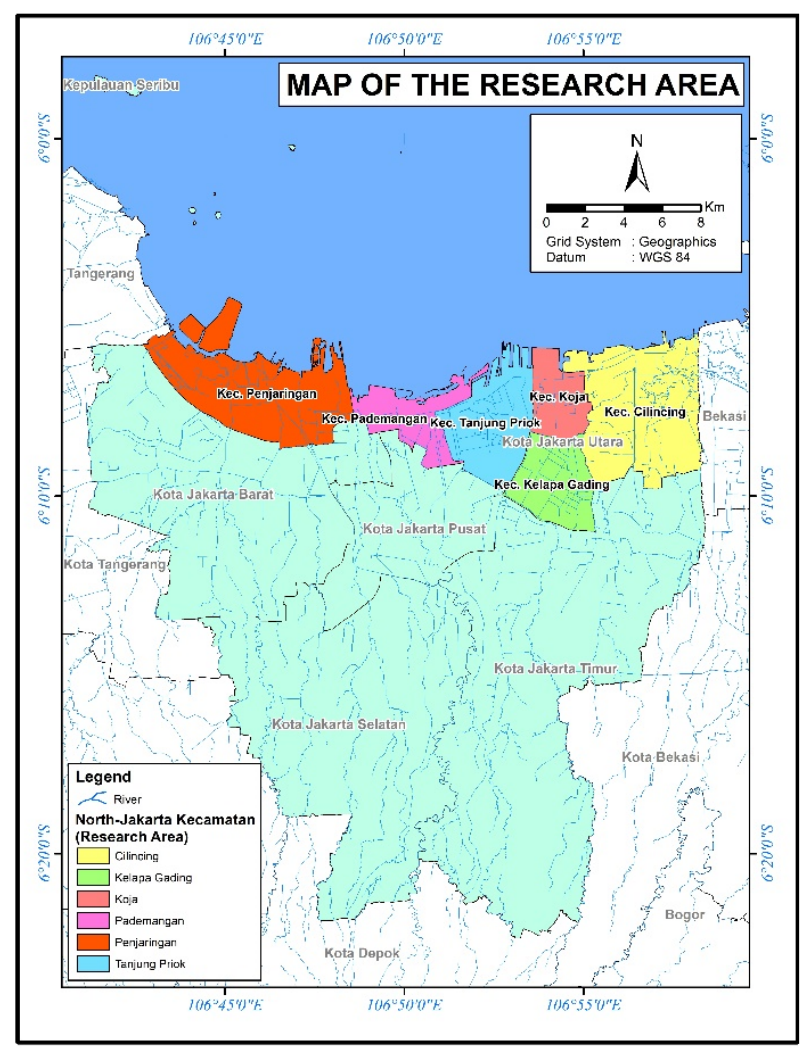

Figure 1. Research area: North Jakarta City, DKI Jakarta Province, Indonesia.

\subsection{Questionnaire Design}

The level of public acceptance is measured by examining community responses to the coastal flooding early warning system based on a questionnaire conducted in communities around the coast of North Jakarta. The higher the average respondent's attitude, the more likely the respondent will have a good acceptance of the coastal flooding early warning model. In our study, the design of the questionnaire was based on four sections: Identity, capacity, knowledge, perception, and attitude (Appendix A). Each section consisted of several closed-ended questions with multiple choice answer options, which we thought was sufficient for the targeted research objectives. The identity section consisted of 10 questions, and the capacity section consisted of 33 questions. The identity and capacity sections were formulated by providing direct questions, either: (a) Multiple-choice questions, where respondents can choose answers based on the available choices, or (b) dichotomous questions, where respondents are only given yes or no choices to make it easier for respondents to understand the questions. To measure knowledge, perception, and attitude, we developed a set of 8,5 , and 6 item questions, respectively. These three variables were expected to describe the public acceptance pattern of a coastal flooding early warning system in settlement areas. These three sections were formulated using scaling questions, where the respondents can choose the available answers on a scale using a given range of values (we use the Likert scale, the easiest to construct as well as the most used by scholars). The Likert scale in the questionnaire is determined by assuming that knowledge is sufficiently represented by answering yes, doubtful, and no. The perception and attitude section had a greater range than knowledge because we wanted to observe variations in answers from respondents ranging from a scale of one (the worst response) to five (the best response).

\subsection{Sample and Data Selection}

The purposive sampling method was used with certain considerations so that the data obtained in the field were more representative according to the research objectives. This was achieved by previously determining the sample candidates that could provide the 
appropriate required data and narrow the objectives of the sample's taker. Respondents were selected based on the people directly affected by coastal flooding and stakeholders directly involved with coastal flooding. The selection was performed so that the response to the research objectives was more precise and contextual.

We selected the research location to cover five sub-districts (local term: Kecamatan) in North Jakarta City. These five districts were selected because they are directly adjacent to the coast, which was the research area of this study. From these five sub-districts, the location was narrowed down to 8 villages (local term used in Jakarta province: Kelurahan), which can be seen in Table 1 .

Table 1. Location of research survey.

\begin{tabular}{cccc}
\hline No & Sub-District & Area $\left.\mathbf{( k m}^{\mathbf{2}}\right)$ & Village \\
\hline 1 & Penjaringan & 45.41 & Pluit \\
2 & Pademangan & 11.92 & Ancol \\
3 & Tanjung Priok & 22.52 & Tanjung Priok and Warakas \\
4 & Koja & 12.25 & Koja Utara \\
5 & Cilincing & 39.7 & Marunda, Kalibaru, and Cilincing \\
\hline
\end{tabular}

The population of North Jakarta City, according to the Statistics Central Bureau in 2018 (local term: Biro Pusat Statistik (BPS)), was 1,716,591 spread across Penjaringan (298,457), Pademangan $(161,322)$, Tanjung Priok $(395,022)$, Koja $(322,367)$, Kelapa Gading $(136,395)$, and Cilincing $(403,028)$. The samples were taken from this population, which represented the research needs using the Slovin formula based on past studies [30].

$$
n=\frac{N}{1+N \alpha^{2}}
$$

where $n$ is the number of samples, $N$ is the total population of North Jakarta, and $\alpha$ is the significance level of $\alpha=0.05$. Thus, the number of samples that were surveyed was calculated as follows:

$$
n=\frac{1,716,591}{1+\left(1,716,591 \times 0.05^{2}\right)} \approx 400 \text { Individuals }
$$

With the following samples distribution shown in Table 2:

Table 2. Samples distribution.

\begin{tabular}{ccccc}
\hline No & Village & Population & Proportion & Samples \\
\hline 1 & Pluit & 52,397 & $13.8 \%$ & 56 \\
2 & Ancol & 28,870 & $7.6 \%$ & 30 \\
3 & Tanjung Priok & 42,072 & $11.1 \%$ & 44 \\
4 & Warakas & 53,347 & $14.0 \%$ & 56 \\
5 & Koja Utara & 34,435 & $9.1 \%$ & 36 \\
6 & Marunda & 31,620 & $8.3 \%$ & 33 \\
7 & Kalibaru & 84,491 & $22.2 \%$ & 89 \\
8 & Cilincing & 52,750 & $13.9 \%$ & 56 \\
& Total & $\mathbf{3 7 9 , 9 8 2}$ & $\mathbf{1 0 0} \%$ & $\mathbf{4 0 0}$ \\
\hline
\end{tabular}

The data used in this study were obtained from a face-to-face questionnaire survey that was conducted in July 2019. Enumerators who collected the data were staff from the Class I Tanjung Priok Maritime Meteorology BMKG Station. All staff had basic knowledge about the coastal flooding early warning system. According to sample selection, in total, 400 questionnaires were distributed based on each predetermined village. All the questionnaires were collected, and the number of valid responses after the exclusion of incomplete questionnaires was 400 (the response rate was 100\%). This excellent response rate occurred due to the use of purposive sampling. 


\subsection{Cross Tabulation}

Validity and reliability tests were conducted prior to the analysis to determine whether the research variables met the requirements for further analysis. The questionnaire that was tested was an instrument used to measure the variables of knowledge, perceptions, and attitudes of society. The results of the statistical calculations for the validity test of each question instrument are presented in Table 3. In addition, the statistical calculations for testing the reliability of each measurement variable are presented in Table 4.

Table 3. Validity test.

\begin{tabular}{cccc}
\hline Research Instruments & Number of Questions & Total of Pearson Correlation Score & Sig. (2-Tailed) \\
\hline Knowledge & 8 & $0.411-0.600$ & 0.000 \\
Perception & 5 & $0.416-0.763$ & 0.000 \\
Attitude & 6 & $0.783-0.859$ & 0.000 \\
\hline
\end{tabular}

Table 4. Reliability test.

\begin{tabular}{cccc}
\hline Variable & Cronbach's Alpha & Number of Question & Valid \& Reliable \\
\hline Knowledge & 0.625 & 8 & $100 \%$ \\
Perception & 0.668 & 5 & $100 \%$ \\
Attitude & 0.906 & 6 & $100 \%$ \\
\hline
\end{tabular}

In accordance with Table 3, the research instrument was found to be valid, as it had a Pearson correlation score higher than 0.3 , and the significance test using a 2-tailed $p$-value was significant under an $\alpha$ level of $5 \%$ indicated by a value of 0 , which is less than 0.05 . In addition, Table 4 indicates that the questionnaire is reliable because the results showed that the Cronbach's Apha value for each variable is more than 0.6. This means that all question instruments (100\%) for each variable (knowledge, perceptions, and attitudes) were valid and reliable, and thus could be used for further analysis.

Furthermore, cross tabulation analysis in this study used a contingency table type with statistical tests using Spearman's Rho rank correlation coefficient to see the relationship amongst variables in the questionnaire [31]. Researchers in analyzing variable relationships widely use this method. The Spearman's Rho rank correlation coefficient method is a non-parametric test method that can express the same variable's intensity and direction at different times. It was defined as:

$$
r_{s}=1-\frac{6}{n\left(n^{2}-1\right)} \sum\left(y_{i}-i\right)^{2}
$$

where $r_{s}$ is spearman correlation coefficient, $y_{i}$ is rating of initial observation, $i$ is chronological order number of observation data $(i=1,2, \ldots, n)$, and $n$ is total length of observation.

\subsection{Path Analysis}

Initially, the data were checked for possible relationships through cross-tabulation and the characteristics of data. Thereafter, path analysis with maximum likelihood estimation method was used in this study. Path analysis is a subset of structural equation modeling (SEM). It used to study direct and indirect effects between variables hypothesized as cause and variables treated as effects [32]. It was used to investigate how knowledge and perceptions affect the determination of community attitudes in accepting the coastal flooding early warning system. This analysis was carried out on respondents' data in the Northern Jakarta area consisting of eight villages observed through a questionnaire, and then the initial description of the path diagram model is presented in Figure 2. 


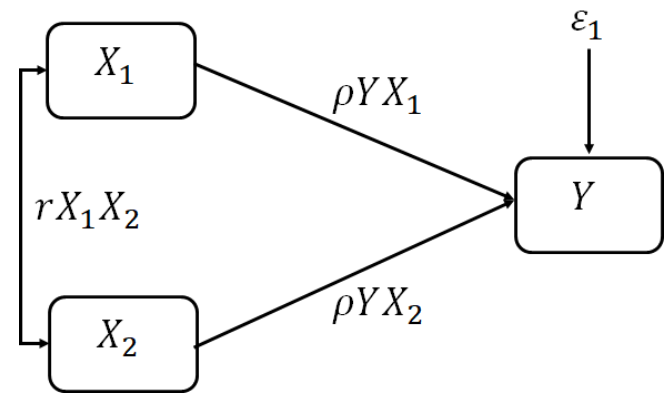

Figure 2. Path diagram model.

In Figure 2, $X_{1}$ is the knowledge variable, $X_{2}$ is the perception variable, and $Y$ is the attitude variable. Symbol $\rho Y X_{1}$ represents path coefficient $X_{1}$ to $Y$. Moreover, path coefficient $X_{2}$ to $Y$ is represented by $\rho Y X_{2}$ symbol. The symbol $r X_{1} X_{2}$ denotes the correlation coefficients of $X_{1}$ and $X_{2}$.

This path analysis model was developed by considering variables as suggested by past studies [33]. Lo, A.Y. [34] and Terpstra, T. [35] are others who have applied SEM in their data analysis. Although in their research they analyzed the relationship between perceptions and behavior regarding flooding, none of them discussed the relationship between the level of public acceptance of the coastal flooding early warning system from the perspective of the community's knowledge and perceptions. This study quantitatively analyzes and compares the relationship of knowledge and perceptions on attitudes, and looks in more detail at the level of public acceptance of the coastal flooding early warning system based on the characteristics of respondents in coastal areas.

\section{Results and Discussion}

Firstly, descriptive analysis was applied to quantitatively describe and summarize the socio-demographic characteristics of the respondents and the research variables (knowledge, perception, and attitude). Lastly, cross-tabulation and path analysis were conducted to examine the relationship between knowledge, perception, and attitude to determine the level of public acceptance of a coastal flooding early warning system.

\subsection{The Respondents' Socio-Demographic Characteristics}

The respondents' socio-demographic characteristics are shown in Figures 3-6. The respondents were grouped into five age groups. The results showed that the age group with the most respondents was the 31-40-year-old group (35\%), and the group with the least was in the $>60$-year-old group $(1.25 \%$ ) (Figure 3 ).
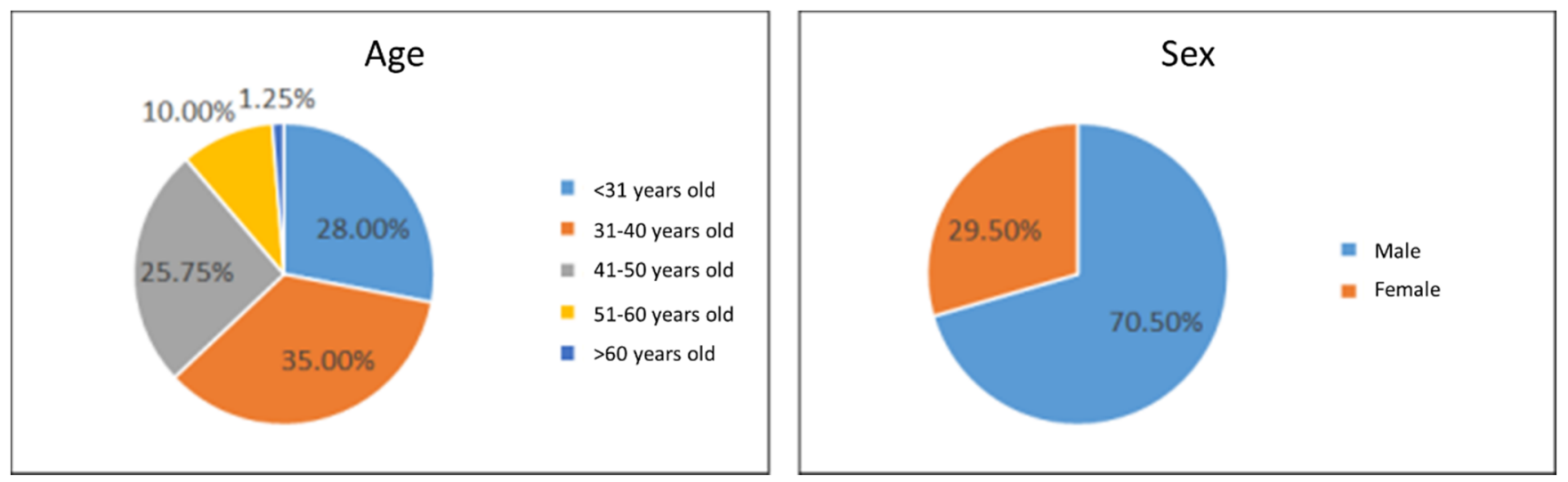

Figure 3. Proportion of age and sex. 



Figure 4. Proportion of level of education and types of occupation.
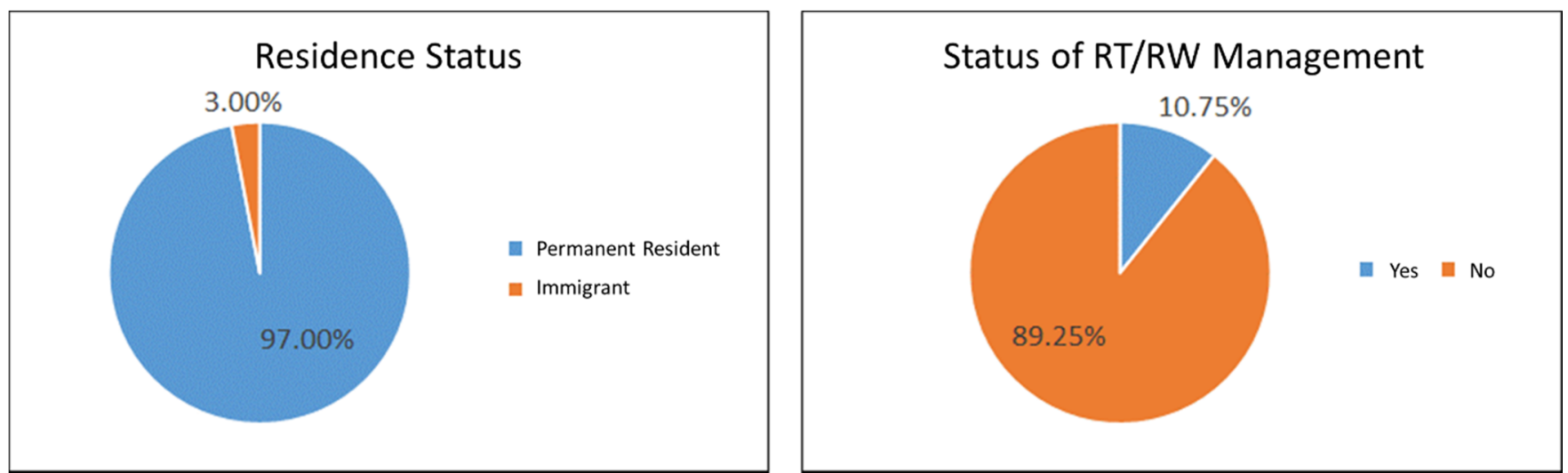

Figure 5. Proportion of citizenship status and status of RT/RW management.

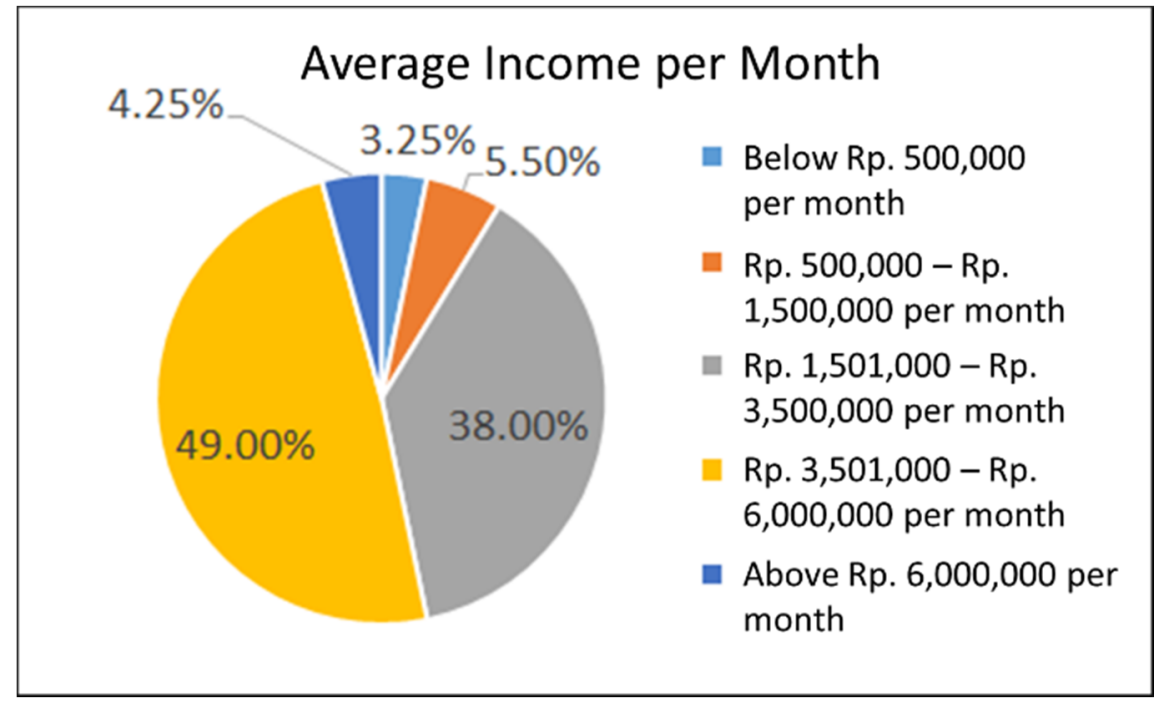

Figure 6. Proportion of monthly average income.

Regarding sex, most respondents were male $(70.5 \%)$, and the remaining respondents were female (29.5\%) (Figure 3).

Based on the level of education, most respondents (55.75\%) had an education level of senior high school/equivalent (local term: SLTA) and at least $1.75 \%$ of them were academy graduates (Figure 4). 
Based on the type of occupation, most respondents (67.25\%) worked as entrepreneurs/selfemployed, and no respondents were working as Indonesian Military Soldiers or Police Officers (local term: TNI or POLRI) (Figure 4).

Based on citizenship status, most respondents (97\%) were permanent residents according to the distribution area of the questionnaire, while the remaining $3 \%$ were residents with a national government ID card (local term: KTP) from outside of Jakarta Province (Figure 5).

Based on the management of RT/RW (the Indonesian term for the lowest administrative area neighborhood consisting of 10-50 families), RW is one level higher than RT, but lower than a village; most respondents $(89.25 \%)$ were not RT/RW administrators. The remaining $10.75 \%$ of the respondents were active members of the local RT/RW management (Figure 5). This indicates that the survey carried out has been evenly distributed to both residents and local stakeholders.

Based on total income, most respondents (49\%) had an income of between Rp. 3,501,000 and 6,000,000 (Rp. is similar to IDR, the currency of Indonesia), and the smallest number of respondents (3.25\%) had an income of $<$ Rp. 500,000 (Figure 6).

The questionnaire results regarding the capacity of the respondents to face coastal flooding and the responses regarding coastal flooding early warnings are provided in Appendix B. In addition, the results indicated that most respondents had lived in coastal areas for more than 20 years, with the majority being native residents, where their residence or houses were mostly privately owned property.

From the survey, the largest proportion of people living in coastal areas were married with 4-6 people living in the same house, followed by 1-3 people in the same house. Based on the questions asked in the questionnaire, most respondents knew the causes and impacts of coastal flooding (i.e., sea level rise and poor drainage channels (gutters)). Based on the answers of the respondents, coastal flooding (local term: Rob-flood due to sea level rise) events occur at uncertain times according to most respondents, with a frequency of 1-3 times per month, each with a duration of $2-3 \mathrm{~h}$ and $0-30 \mathrm{~cm}$ depth.

Most respondents said that the dissemination of information related to flooding was rare by the head of the local RT/RW, as they did not participate in associations or organizations related to flood disasters. Some efforts have been made to deal with flooding, such as house reconstruction efforts like elevating the ground floor of houses as the most impact felt due to flooding is property damage (houses, vehicles, household utensils). Many respondents stated that the reason for living in the location where they are currently living is because they have lived there for a long time, even though when viewed from the survey results, it was found that the drainage conditions (waterways and/or gutters) in the neighborhood where most respondents were located could properly flow, but some of the drainage systems were clogged with mud and/or trash.

According to most respondents, there was no flood warning system in the neighborhood where they lived, and they commonly obtained the information/news related to flood disasters that occurred (including flood predictions) from news sources such as newspapers, television, or the internet. When they were questioned about where to go to save themselves when a flood occurs, they generally answered that they would remain at home as the modes of transportation mostly used to evacuate during such an emergency were motorbikes.

When they were asked about the type of fund allocation that is available, $69 \%$ of respondents said they did not have any funds allocated for flood disasters due to the low-income level in coastal areas. Moreover, according to most respondents, there was no financial assistance during or after flood disasters. The government provided aid during and after flood disasters; the assistance provided was mostly in the form of food supplies, followed by the provision of body protection such as clothes and blankets.

Previous research [36] suggested that the information needs of local residents and access to information are integral components in the process of public understanding. This theory was tested out for the government mitigation scheme. 
Based on the answers to these questions, the capacity of coastal communities to deal with coastal flooding was observed. Of note, three-fourths of the respondents already knew the causes and impact of coastal flooding. However, the community rarely received information from the head of the RT/RW. This information is important because it impacts the lack of community participation in coastal flooding management. There is no early warning coastal flooding system, even though the questionnaire results showed that the government provides the most assistance to the community, both in terms of funding for disaster management and repairing drainage systems in coastal areas. It can be concluded that a large amount of government involvement makes the dissemination of the coastal flooding early warning system very critical for improving the level of public acceptance based on existing capacities.

\subsection{Descriptive Analysis of Research Variables}

This section describes the dynamics and distribution of the respondents' answers to the questions determining the variables of knowledge, perceptions, and attitudes. Recapitulation was performed to determine the average score of each variable, which was then compared, observed, and analyzed based on the sub-district. Referring to the minimum and maximum values described in Section 2.2, the existing median value for the knowledge variable was 2, and the value for the perception and attitude variables was 3 .

Table 5 shows that Warakas village had the lowest knowledge, with an average score value of 2.30. The highest average score value was in Koja Utara village (3.00). This indicated that the average community on the coast of North Jakarta had little knowledge about coastal flooding and the early warning of coastal floods in the community area.

Table 5. Average score results on knowledge, perception, and attitude evaluation of coastal flooding early warning system in North Jakarta villages.

\begin{tabular}{ccccc}
\hline \multirow{2}{*}{ Village } & \multirow{2}{*}{$\begin{array}{c}\text { Number of } \\
\text { Samples }\end{array}$} & \multicolumn{3}{c}{ Average Score Value } \\
\cline { 3 - 5 } & & Knowledge & Perception & Attitude \\
\hline Pluit & 56.00 & 2.36 & 2.82 & 3.79 \\
Ancol & 30.00 & 2.63 & 2.53 & 4.47 \\
Tanjung Priok & 44.00 & 2.70 & 3.20 & 4.07 \\
Warakas & 56.00 & 2.30 & 3.59 & 4.14 \\
Koja Utara & 36.00 & 3.00 & 3.50 & 4.81 \\
Marunda & 33.00 & 2.85 & 2.94 & 4.70 \\
Kali Baru & 89.00 & 2.99 & 2.44 & 4.57 \\
Cilincing & 56.00 & 2.52 & 2.75 & $\mathbf{4 . 7 5}$ \\
Total & $\mathbf{4 0 0 . 0 0}$ & $\mathbf{2 . 3 3}$ & 3.58 & \\
\hline
\end{tabular}

Based on the context of public perception about the coastal flooding early warning information system, Kali Baru village had the lowest average score (2.44) compared to other urban villages, while the highest average score was in Warakas village (3.59). In addition, according to the average score for each village, the coastal communities of North Jakarta had a common perception that a coastal flooding early warning system would be suitable as a solution to manage coastal flooding.

The questionnaire results showed that there were various responses regarding the respondents' perception of a coastal flooding early warning system that was already implemented in the community (i.e., local wisdom); $44.75 \%$ of respondents stated that they agreed or strongly agreed that the traditional early warning system was sufficient for the flood evacuation process. Nevertheless, the remaining $55.25 \%$ of respondents thought that it would be necessary to add another early warning system besides the traditional system of local wisdom.

The recapitulation results showed that $62.5 \%$ respondents thought that there was no local wisdom related to a flood early warning system. In contrast, $20.25 \%$ of the respondents stated that there was local wisdom in responding to early warning systems, 
such as traditional equipment like kentongan (a drum made from bamboo or wood that is struck to sound an alarm) or announcements from places of worship (such as a mosque). The remaining $17.25 \%$ of respondents suggested that there was already a flood warning system where they live in the form of technology conveying information via the internet. The local wisdom that exists in the community related to flood disasters and flood predictions includes paying attention to natural signs ( $28.75 \%$ of respondents) and information from neighbors and families and local government officials (27.25\% of respondents). The remaining $44 \%$ of respondents received news from newspapers, $\mathrm{TV}$, and the internet.

For the community attitude variable, the lowest average score was in Cilincing village (3.75), while the highest score was 4.81 in Koja Utara village. Overall, we concluded that the coastal communities of North Jakarta think that it is quite appropriate to use an early warning system to manage coastal flooding disasters.

Table 5 shows the community's level of knowledge, perceptions, and attitudes more clearly based on each village observed in the study. This may be closely related to the community's social strata in Cilincing and Pluit villages, which are not directly located on the coast.

\subsection{Cross Tabulation}

The cross tabulation analysis was conducted to determine the relationship amongst knowledge, perception, and attitude variables. The results of this analysis are presented in Table 6 which shows that these three variables in the research correlates with each other.

Table 6. Cross tabulation.

\begin{tabular}{cccc}
\hline Instruments & Knowledge & Perception & Attitude \\
\hline Knowledge & 0 & There is correlation & There is correlation \\
Perception & There is correlation & 0 & There is correlation \\
Attitude & There is correlation & There is correlation & 0 \\
\hline
\end{tabular}

If seen in more detail as in Table 7 , it can be seen how the relationship between the characteristics of the respondents to the variables of knowledge, perception, and attitude.

Table 7. Relationship between respondents' characteristics to variables of knowledge, perception, and attitude using cross tabulation analysis.

\begin{tabular}{cccc}
\hline Respondents' Characteristics & Knowledge & Perception & Attitude \\
Age & 0 & 0 & There is correlation \\
Gender & 0 & 0 & 0 \\
Education & There is correlation & There is correlation & There is correlation \\
Occupation & There is correlation & There is correlation & 0 \\
Residence Status & There is correlation & 0 & There is correlation \\
Status RT $/$ RW Management & There is correlation & 0 & There is correlation \\
Average Income & There is correlation & There is correlation & 0 \\
\hline
\end{tabular}

From Table 7, the characteristics that have a relationship with these three variables are education and average income. Meanwhile, occupation, residence status, and RT/RW management status are related to the two variables observed. Furthermore, age is only related to one variable. In addition, it shows that gender does not have any impact in responding to answers regarding the variables observed.

The highest correlation coefficient between the community variables' knowledge and attitude based on Table 8 was found in Kali Baru Village (0.687). This implied that the Kali Baru community tends to have a strong relationship between their knowledge and the community's attitude regarding the development of an early warning system of coastal flooding. The highest correlation coefficient between perceptions and community attitudes variables was in Warakas village by 0.622 , which showed that Warakas community tends 
to have a strong relationship between the community's perceptions and the community attitudes regarding the development of a coastal flooding early warning system.

Table 8. Correlation coefficient amongst research variables on villages basis using Spearman's Rho analysis.

\begin{tabular}{|c|c|c|c|c|}
\hline Variable & Village & Knowledge & Perception & Attitude \\
\hline \multirow{8}{*}{ Knowledge } & Ancol & 1.000 & -0.632 & 0.625 \\
\hline & Cilincing & 1.000 & 0.291 & 0.139 \\
\hline & Kali Baru & 1.000 & 0.284 & 0.687 \\
\hline & Koja Utara & 1.000 & 0.110 & 0.013 \\
\hline & Marunda & 1.000 & 0.264 & 0.452 \\
\hline & Pluit & 1.000 & 0.134 & 0.265 \\
\hline & Tanjung Priok & 1.000 & -0.002 & 0.165 \\
\hline & Warakas & 1.000 & 0.032 & 0.327 \\
\hline \multirow{8}{*}{ Perception } & Ancol & -0.632 & 1.000 & -0.051 \\
\hline & Cilincing & 0.291 & 1.000 & -0.122 \\
\hline & Kali Baru & 0.284 & 1.000 & 0.313 \\
\hline & Koja Utara & 0.110 & 1.000 & 0.511 \\
\hline & Marunda & 0.264 & 1.000 & 0.329 \\
\hline & Pluit & 0.134 & 1.000 & 0.389 \\
\hline & Tanjung Priok & -0.002 & 1.000 & 0.069 \\
\hline & Warakas & 0.032 & 1.000 & 0.622 \\
\hline \multirow{8}{*}{ Attitude } & Ancol & 0.625 & -0.051 & 1.000 \\
\hline & Cilincing & 0.139 & -0.122 & 1.000 \\
\hline & Kali Baru & 0.687 & 0.313 & 1.000 \\
\hline & Koja Utara & 0.013 & 0.511 & 1.000 \\
\hline & Marunda & 0.452 & 0.329 & 1.000 \\
\hline & Pluit & 0.265 & 0.389 & 1.000 \\
\hline & Tanjung Priok & 0.165 & 0.069 & 1.000 \\
\hline & Warakas & 0.327 & 0.622 & 1.000 \\
\hline
\end{tabular}

As seen in Table 8, several relationship anomalies occur in several urban villages that result in negative correlations. Ancol village has a high negative correlation $(-0.63)$ for the relationship between the knowledge and the attitude variables. Meanwhile, Cilincing and Ancol villages ( -0.122 and -0.051 ) show a low negative correlation between the perception and the attitude variables. The negative correlation related to the relationship between the knowledge and the attitude variables indicates that the higher the knowledge of Ancol community, the smaller the community's perception of the coastal flooding early warning model, and this shows a contradiction to a study conducted by Jing Huang [37] stating that there is a positive correlation between knowledge and attitudes related to behavior of flood protection handling. This contradiction can be traced by looking at the characteristics of the respondents and the community capacities in the Ancol Village in further research.

\subsection{Path Analysis}

The results of path analysis calculation as seen in Table 9, show that the knowledge variable has a direct effect on the attitude variable by $7.3 \%$. Furthermore, Figure 7 indicates that $t_{\text {test }}$ is 6.18 , as shown from the test results of knowledge influence on the community's attitudes. The value of $t_{\text {test }}(6.18)$ is higher than the value of $t_{\text {table }}$ (1.96). This means that 
public knowledge of the coastal flooding early warning model has a significant effect on the attitudes of the community towards the coastal flooding early warning model.

Table 9. Correlation and influence amongst variables using path analysis.

\begin{tabular}{|c|c|c|c|c|}
\hline Effect & Correlation & Influence & Value of Influence & $\%$ \\
\hline \multirow{4}{*}{ Direct Effect (DE) } & \multirow{2}{*}{$X_{1} \rightarrow Y$} & $\rho Y X_{1} \times \rho Y X_{1}$ & \multirow{2}{*}{0.073} & \multirow{2}{*}{$7.3 \%$} \\
\hline & & $0.27 \times 0.27$ & & \\
\hline & \multirow{2}{*}{$X_{2} \rightarrow Y$} & $\rho Y X_{2} \times \rho Y X_{2}$ & \multirow{2}{*}{0.160} & \multirow{2}{*}{$16.0 \%$} \\
\hline & & $0.40 \times 0.40$ & & \\
\hline Indirect Effect (IE) & - & 0.000 & 0.000 & $0.0 \%$ \\
\hline \multirow{6}{*}{ Total Effect (TE) } & \multirow{2}{*}{$X_{1}$} & $D E X_{1}+I E$ & \multirow{2}{*}{0.073} & \multirow{2}{*}{$7.3 \%$} \\
\hline & & $0.073+0$ & & \\
\hline & \multirow{2}{*}{$X_{2}$} & $D E X_{2}+I E$ & \multirow{2}{*}{0.160} & \multirow{2}{*}{$16.0 \%$} \\
\hline & & $0.160+0$ & & \\
\hline & \multirow{2}{*}{$X_{1}$ dan $X_{2}$} & $T E X_{1}+T E X_{2}$ & \multirow{2}{*}{0.233} & \multirow{2}{*}{$23.3 \%$} \\
\hline & & $0.073+0.160$ & & \\
\hline Residue & $\varepsilon_{1} \rightarrow Y$ & $1-0.233$ & 0.767 & $76.7 \%$ \\
\hline
\end{tabular}

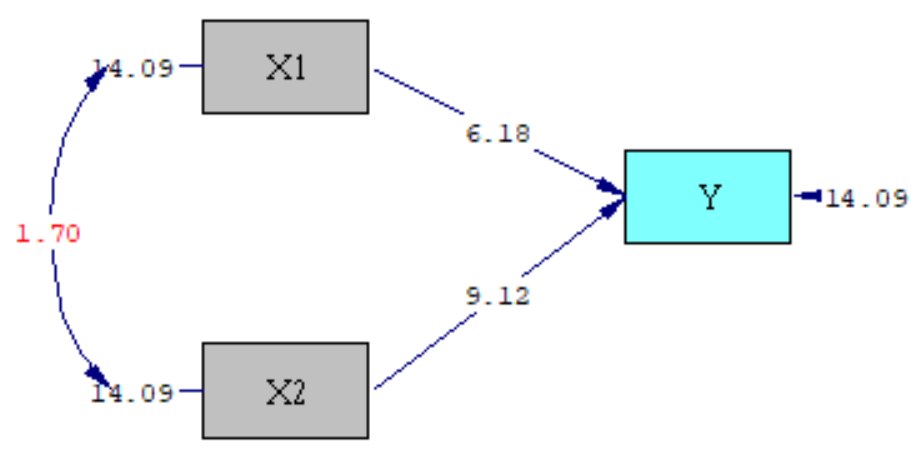

Chi-Square=0.00, df=0, P-value $=1.00000$, RMSEA $=0.000$

Figure 7. Significant test of variables.

The path coefficient between knowledge and community's attitudes is 0.37 , as shown in Figure 8, which is positive. This means that the higher the community's knowledge about the coastal flooding early warning model, the community's attitude in responding to the coastal flooding early warning model that is formed will increase.

Table 10 strengthens the previous correlation analysis results that Kali Baru Village has the highest knowledge relationship on community attitudes regarding the coastal flooding early warning model compared to other villages. This is indicated by many respondents, the majority of whom have a senior high-level education compared to other villages. This analysis is reinforced by a previous study [38], which states that individuals with higher education are less likely to be affected by flooding than individuals with low education. These results are also consistent with other studies [39], which showed that respondents who were knowledgeable about floods felt higher adaptive capacity and were more likely to take adaptive measures. 


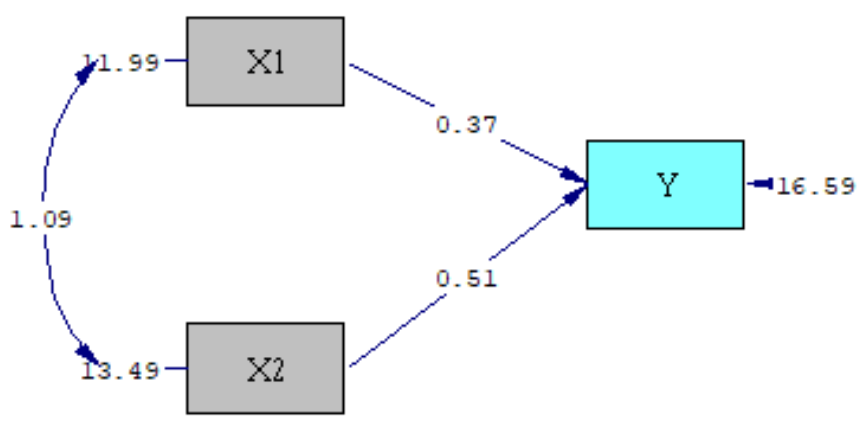

Chi-Square=0.00, df $=0, \mathrm{P}-$ value $=1.00000, \mathrm{RMSEA}=0.000$

Figure 8. Estimate of path diagram coefficient.

Table 10. Respondent based on education.

\begin{tabular}{|c|c|c|c|c|c|c|c|}
\hline Village & $\begin{array}{l}\text { Not Completed in } \\
\text { Primary School }\end{array}$ & $\begin{array}{l}\text { Primary } \\
\text { School }\end{array}$ & $\begin{array}{c}\text { Junior High } \\
\text { School }\end{array}$ & $\begin{array}{l}\text { Senior High } \\
\text { Scool }\end{array}$ & Diploma & $\begin{array}{c}\text { Higher } \\
\text { Education }\end{array}$ & Total \\
\hline Ancol & & 5 & 6 & 19 & & & 30 \\
\hline Cilincing & & 1 & 14 & 40 & & 1 & 56 \\
\hline Kali Baru & 2 & 20 & 24 & 43 & & & 89 \\
\hline Koja Utara & & 4 & 8 & 20 & 2 & 2 & 36 \\
\hline Marunda & & 7 & 12 & 14 & & & 33 \\
\hline Pluit & 5 & 7 & 12 & 30 & 1 & 1 & 56 \\
\hline Tanjung Priok & & 4 & 7 & 28 & & 5 & 44 \\
\hline Warakas & 1 & 1 & 8 & 29 & 4 & 13 & 56 \\
\hline Total & 8 & 49 & 91 & 223 & 7 & 22 & 400 \\
\hline
\end{tabular}

Table 10 shows the remarkably diverse variations in education levels in coastal communities, it can be used as a reference for determining the method of dissemination that must be carried out so that the level of public acceptance of the coastal flooding early warning model becomes better. Methods of delivery that can be carried out to embrace all society elements without paying attention to education level include the dissemination of information through social media, printable media, or through the official website of related agencies/institutions.

Table 9 also shows that the perception variable has a direct influence on the attitude variable by $16.0 \%$. The test results on the effect of perception on the community's attitudes obtained a $t_{\text {test }}$ as much as 9.12, as seen in Figure 7. Accordingly, the value of $t_{\text {test }}(9.12)$ is higher than the value of $t_{\text {table }}(1.96)$. This indicates that the community's perception on the coastal flooding early warning model has a significant effect on their attitudes towards the coastal flooding early warning model.

The path coefficient between perceptions and the community's attitudes is 0.51 positive, as shown in Figure 8. This means that the higher the public perception of the coastal flooding early warning model, the community's attitude in responding to the coastal flooding early warning model that is formed will increase.

Table 11 shows that respondents in Warakas and Kali Baru Villages have a high proportion of respondents with a duration of stay of more than 20 years, higher than $50 \%$ compared to other villages. This strengthens the results of the correlation analysis, which states that people's perceptions in Warakas Village on their attitudes regarding the coastal flooding early warning model have the highest relationship compared to other villages. People who have lived in an area for a long time make the perception formed in the community better in coastal flooding disasters because they are more familiar with the 
condition of the area. It affects the increase of the level of public acceptance. The results of this analysis are in accordance with other researchers [40], which shows that cultural and historical relationships with place are a significant driver of their desire to stay on riverbanks affected by flooding.

Table 11. Respondents based on duration of stay.

\begin{tabular}{ccccc}
\hline Village & $\mathbf{0 - 1 0}$ Years & $\mathbf{1 1 - 2 0}$ Years & $\mathbf{2 0 \text { Years }}$ & Total \\
\hline Ancol & 8 & 8 & 14 & 30 \\
Cilincing & 19 & 9 & 28 & 56 \\
Kali Baru & & 22 & 67 & 89 \\
Koja Utara & 8 & 8 & 20 & 36 \\
Marunda & 10 & 5 & 18 & 33 \\
Pluit & 17 & 24 & 15 & 56 \\
Tanjung Priok & 10 & 14 & 20 & 44 \\
Warakas & 5 & 19 & 32 & 56 \\
Total & $\mathbf{7 7}$ & $\mathbf{1 0 9}$ & $\mathbf{2 1 4}$ & $\mathbf{4 0 0}$ \\
\hline
\end{tabular}

Lastly, knowledge and perception variables simultaneously influence the attitude variable by $23.3 \%$. Therefore, such a simultaneously great influence of knowledge and perception variables on the attitude variable indicates that the community's attitude in responding to the coastal flooding early warning model can be explained by knowledge and perception variables simultaneously by $23.3 \%$. Besides, the remaining $76.7 \%$ is explained by other variables not investigated in the research.

\section{Conclusions}

In this study, we concluded that the level of public acceptance toward the development of an early warning system is excellent as proven by the high average score of the respondents' attitude, i.e., agreeing with the establishment of an early warning system to manage coastal flooding (4.15). When the correlation between knowledge and perceptions toward community attitudes was analyzed using path analysis, the results showed a relationship with low effect. For further research, it is necessary to consider other variables that may significantly influence the determination of community attitudes in responding to coastal flooding early warning systems. This study could be used to improve the development of the coastal flooding early warning system by considering the level of public acceptance. Since knowledge and perspective connect to community attitudes and describe the public acceptance, therefore conducting socialization about coastal flooding and its system at the RT/RW level is needed before the implementation. It is hoped that the socialization could increase community attitudes toward accepting information about the system. Furthermore, our findings could be used as a mitigation reference for the local government to determine policies on the development of an early warning system.

Author Contributions: Conceptualization, N.F.R.; methodology, R.F.S., H.R., and W.S.; software, M.H.N.; validation, W.S., R.F.S., H.R., and N.F.R.; formal analysis, N.F.R. and M.H.N.; resources, N.F.R.; data curation, M.H.N.; writing—original draft preparation, N.F.R. and M.H.N.; writingreview and editing, N.F.R., R.F.S., H.R., W.S., and M.H.N.; visualization, M.H.N.; supervision, R.F.S. All authors have read and agreed to the published version of the manuscript.

Funding: This research received no specific grant from any funding agency in the public, commercial, or non-for-profit sectors.

Informed Consent Statement: Informed consent was obtained from all subjects involved in the study.

Data Availability Statement: The data presented in this study are available on request from the corresponding author. The data are not publicly available due to containing information that could compromise research participant privacy/consent.

Conflicts of Interest: The authors declare no conflict of interest. 


\section{Appendix A}

\section{Questionnaire}

A. Respondent's Identity

Please complete the questions or put a checklist in the box provided

A1. Name:

A2. Address:

A3. E-mail/Phone Number:

A4. Age:

\begin{tabular}{lll}
\hline$\square \quad$ Less than 31 Years Old & $\square \quad 50-60$ Years Old \\
\hline$\quad 31-40$ Years Old & $\square \quad$ Older than 60 Years Old \\
\hline$\square \quad 41-50$ Years Old &
\end{tabular}

A5. Gender:

$\square$ Male $\square$ Female

A6. Latest Education:

$\begin{array}{lll}\square \text { Did not complete primary school } & \square \text { Senior high school } \\ \square \text { Primary school } & \square \text { Diploma } \\ \square \text { Junior high school } & \square \text { Higher Education }\end{array}$

A7. Occupation:

$\begin{array}{llll}\square & \text { Civil servants } & \square & \square \text { General employees } \\ \square \text { Military/police } & \square & \square \text { Retired } \\ \square \text { Entrepreneur } & & \end{array}$

A8. Residence Status:

$\square$ Permanent resident $\quad \square$ Immigrant

A9. Status of RT/RW Management:

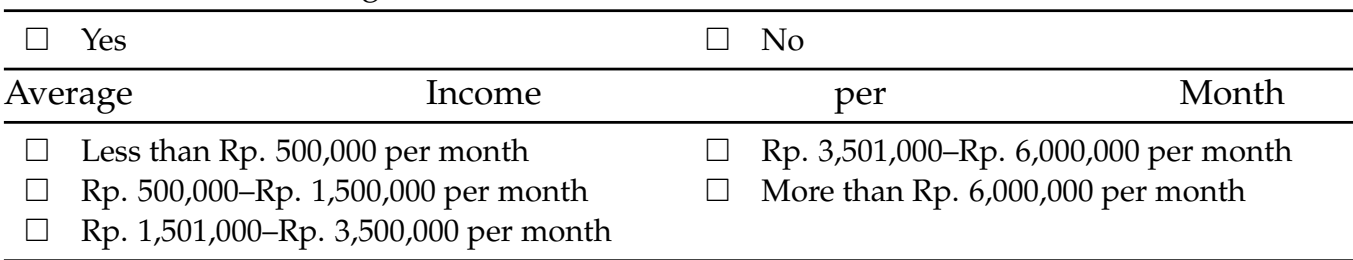

B. Respondent's Capacity

Please choose one answer that best represents your condition, by marking the checklist and completing the entries in the box provided

B1. How long do you stay in this location?
$\square \quad 0-10$ years
$\square \quad$ 10-20 years
More than 20 years

B2. Reasons for staying in this location:
$\square \quad$ Native resident
$\square$ Live with relatives
Close to workplaces
$\square \quad$ Live with spouse
$\square$ Others

B3. Status of residence:

\begin{tabular}{lll}
\hline$\square$ Owner & $\square$ Rent \\
$\square$ Family-owned house & $\square$ Others \\
$\square$ Join residence &
\end{tabular}

B4. Are you married?

$\square$ Yes $\square$ No


B5. How many people do you live with?
$\square$ 1-3 people
7-9 people
$\square$ 4-6 people
$\square \quad$ More than 9 people

B6. Do you know the causes and impacts of coastal flooding?
$\square$ Yes
$\square \quad$ No

B7. Which do you think is the biggest cause of coastal flooding?
$\square$ Land subsidence
$\square \quad$ Excessive use of groundwater
Poor drainage
$\square \quad$ Waste

$\square \quad$ Sea level rise

B8. In your opinion, when does coastal flooding usually occur?
$\square$ Uncertain
$\square$ During full moon
$\square \quad$ When the rainfall is high

B9. How many flood events occur in a month?
$\square \quad$ No occurrence
4-5 times
$\square \quad 1-3$ times
$\square$ More than 5 times

B10. How long will the floods recede?
$\square$ One $\mathrm{h}$
More than $3 \mathrm{~h}$
$\square \quad 2-3 \mathrm{~h}$

B11. What is the depth of the water during a flood?
$\square \quad 0-30 \mathrm{~cm}$
More than $50 \mathrm{~cm}$
$\square \quad 31-50 \mathrm{~cm}$

B12. Has the head of RT/RW in your neighborhood ever provided information about floods?
$\square \quad$ Never
$\square$ Often
$\square$ Rarely
Always
$\square$ Once a time

B13. Do you participate in any organizations related to flood disasters?

\begin{tabular}{ll}
\hline Yes & $\square$ No
\end{tabular}

B14. What is the ownership status of your house?
$\square$ Government assistance
Own property
$\square$ Rent

B15. What kind of house?

$\begin{array}{lll}\square & \text { Not permanent } & \square \text { Permanent } \\ \square & \text { Semi-permanent } & \end{array}$

B16. How large is the building you live in?
$\square \quad$ Less than $21 \mathrm{~m}^{2}$
$\square 21 \mathrm{~m}^{2}$
$45 \mathrm{~m}^{2}$
$\square \quad 36 \mathrm{~m}^{2}$
$\square \quad$ More than $45 \mathrm{~m}^{2}$

B17. How old is the building you live in?
$\square$ Less than 10 years
$\square \quad$ 10-20 years
$\square \quad$ More than 20 years

B18. How many floors are in the building you live in?
$\square$ One storey
$\square$ Two storey
High rise

B19. What house reconstruction efforts have you done in response to the flood?
$\square \quad$ Raise the ground floor
$\square$ Build the drainage in front of the house
$\square$ Increase the storey
Nothing
$\square$ Build embankments to withstand the water 
B20. What impact did you feel when you were hit by the flood?

$\square$ Properties damage (houses, vehicles, household appliances)

$\square$ Cut off access to utilities (roads, clean water, electricity, telecommunications)

Various kinds of diseases arise

$\square$ Casualties/injuries

B21. What is your reason for staying in your current location?

$\square$ Close to workplaces

Have been living in the area for a long time

$\square$ Close to family

B22. What is the condition of the drainage in your neighborhood?

$\square$ Flows $\square$ Puddle

$\square$ Clogged up (mud, waste)

B23. What kind of flood warning system is available in your neighborhood?

$\square$ Traditional (Kentongan, an announcement from the mosque)

There is no system

$\square$ Flood warning system through technology (internet)

B24. What sources of information do you usually get regarding flood events? (including flood predictions)

$\square \quad$ See natural signs

$\square \quad$ Information from local government

$\square$ Information from neighbors/family officials

$\square$ Information from newspaper/TV/Internet

B25. Where do you usually evacuate if there is a flood event?

$\square$ House of relatives $\quad \square$ Hotel

$\square$ Disaster posts provided by the government $\quad \square$ Stay at home

$\square$ Open field/tent

B26. What transportation do you use to evacuate during an emergency?

$\square$ Wooden boat $\quad \square$ Car

$\square$ Inflatable boat

$\square$ Motorcycle

B27. What types of fund allocations do you have in response to the flood disaster?
$\square$ Savings
$\square \quad$ Life insurance
Bank loans
$\square$ Property insurance
$\square \quad$ Investment
$\square$ No fund allocations

B28. During and after the flood event, did you have financial assistance?

$\square$ Yes, it is sufficient during the flood $\quad \square$ Nothing helps

$\square$ Yes, but not quite sufficient

B29. Who helped you during and after the flood event?
$\square$ Government
Relatives
$\square$ Non-governmental organization
$\square \quad$ Private parties

B30. What kind of assistance was provided?
$\square$ Food supply
$\square$ Clothes and blankets
Home improvement
$\square$ Money

$\square$ Medical examination

B31. How much money did you spend to recover from the flood?

$\square \quad$ Less than Rp. 100,000

$\square$ Rp. $100,000-$ Rp. 500,000

Rp. 500,000-Rp. $1,000,000$

More than Rp. $1,000,000$ 
B32. How much money did you save in a month?

\begin{tabular}{lll}
\hline$\square$ No savings & $\square$ Rp. 500,000-Rp. 1,000,000 \\
$\square$ Less than Rp. 250,000 & $\square$ More than Rp. 1,000,000 \\
$\square$ Rp. 250,000-Rp. 500,000 &
\end{tabular}

B33. How much money did you spend in a month?

$\begin{array}{llll}\square & \text { Less than Rp. } 500,000 & \square & \text { Rp. 1,500,000-Rp. 2,000,000 } \\ \square & \text { Rp. 500,000-Rp. 1,000,000 } & \square \text { More than Rp. 2,000,000 } \\ \square & \text { Rp. 1,000,000-Rp. 1,500,000 } & \end{array}$

C. Respondent's Knowledge

Please choose one answer that best represents the condition of your knowledge, by marking the checklist and completing the entries in the boxes provided.

\begin{tabular}{|c|c|c|c|c|}
\hline \multirow{2}{*}{ Number } & \multirow{2}{*}{ Questions } & \multicolumn{3}{|c|}{ Response } \\
\hline & & Yes & Doubtful & No \\
\hline 1 & Do you know what is meant by coastal flooding? & & & \\
\hline 2 & Do you know the causes of coastal flooding? & & & \\
\hline 3 & Do you know the signs of coastal flooding? & & & \\
\hline 4 & $\begin{array}{l}\text { Do you think the occurrence of coastal flooding can be detected by simply } \\
\text { looking at the occurrence of tides? }\end{array}$ & & & \\
\hline 5 & $\begin{array}{l}\text { Do you feel that the warning information about coastal floods is only done } \\
\text { in a traditional way? (Using Kentongan, announcements from the mosque) }\end{array}$ & & & \\
\hline 6 & Do you know what is meant by coastal flooding early warning? & & & \\
\hline 7 & $\begin{array}{l}\text { Do you feel the need for an application regarding early warning from the } \\
\text { government before coastal flooding occurs? }\end{array}$ & & & \\
\hline 8 & $\begin{array}{l}\text { Would you get better benefit if early warning was changed from traditional } \\
\text { system to technology? }\end{array}$ & & & \\
\hline
\end{tabular}

D. Respondent's Perception

Please choose one answer that best represents your perception, by marking the checklist in the box provided.

\begin{tabular}{|c|c|c|c|c|c|c|}
\hline \multirow[b]{2}{*}{ Number } & \multirow[b]{2}{*}{ Questions } & \multicolumn{5}{|c|}{ Response } \\
\hline & & $\begin{array}{c}\text { Very } \\
\text { Inappropriate }\end{array}$ & Inappropriate & $\begin{array}{c}\text { Quite } \\
\text { Appropriate }\end{array}$ & Appropriate & $\begin{array}{c}\text { Very } \\
\text { Appropriate }\end{array}$ \\
\hline
\end{tabular}

Is the traditional coastal flooding

1 early warning sufficient to be considered for the next flood evacuation process? Are the efforts made by the government regarding the

2 dissemination of coastal flooding early warning information in accordance with what is needed? Does the coastal flooding early

3 warning system affect the preparedness actions that you will take?

In your opinion, will the existence of a coastal flooding early warning

4 information system help you to overcome the enormous losses from coastal flooding? Does the coastal flooding early 5 warning system make you play an active role in coordinating the evacuation process? 


\section{E. Respondent's Attitude}

Please choose one answer that best represents your attitude, by marking a checklist in the box provided.

\begin{tabular}{|c|c|c|c|c|c|c|}
\hline \multirow[b]{2}{*}{ Number } & \multirow[b]{2}{*}{ Questions } & \multicolumn{5}{|c|}{ Response } \\
\hline & & $\begin{array}{l}\text { Strongly } \\
\text { Disagree }\end{array}$ & Disagree & $\begin{array}{l}\text { Quite } \\
\text { Agree }\end{array}$ & Agree & $\begin{array}{c}\text { Strongly } \\
\text { Agree }\end{array}$ \\
\hline 1 & $\begin{array}{l}\text { Do you agree if the government establishes an information } \\
\text { system for coastal flooding early warnings? }\end{array}$ & & & & & \\
\hline 2 & $\begin{array}{l}\text { Do you agree if the coastal flooding early warning } \\
\text { information system is socialized to RW level in coastal areas? }\end{array}$ & & & & & \\
\hline 3 & $\begin{array}{l}\text { Do you agree if the coastal flooding early information } \\
\text { system is socialized to all levels of coastal communities } \\
\text { through social media and other communication media? }\end{array}$ & & & & & \\
\hline 4 & $\begin{array}{l}\text { Do you agree that the coastal flooding information system } \\
\text { can minimize the impact of resulting losses? }\end{array}$ & & & & & \\
\hline 5 & $\begin{array}{l}\text { Do you agree that the government must act to evacuate } \\
\text { residents as soon as the coastal flooding early warning } \\
\text { information system has been issued? }\end{array}$ & & & & & \\
\hline 6 & $\begin{array}{l}\text { Do you agree if you are asked to be involved in activities to } \\
\text { inform coastal flooding early warnings? }\end{array}$ & & & & & \\
\hline
\end{tabular}

Source: Author's contributions.

\section{Appendix B}

Questionnaire results of respondent's capacity.

\begin{tabular}{|c|c|c|c|c|c|}
\hline $\begin{array}{l}\text { B1. How long do you } \\
\text { stay in this location? }\end{array}$ & Responses & $\%$ & $\begin{array}{l}\text { B2. Reasons for staying } \\
\text { in this location }\end{array}$ & Responses & $\%$ \\
\hline $0-10$ years & 77 & $19.3 \%$ & Native resident & 168 & $42.0 \%$ \\
\hline $0-20$ years & 109 & $27.3 \%$ & Live with relatives & 107 & $26.8 \%$ \\
\hline$>20$ years & 214 & $53.5 \%$ & Live with spouse & 47 & $11.8 \%$ \\
\hline \multirow[t]{3}{*}{ Total } & 400 & $100.0 \%$ & Close to workplaces & 45 & $11.3 \%$ \\
\hline & & & Others & 33 & $8.3 \%$ \\
\hline & & & Total & 400 & $100.0 \%$ \\
\hline B3. Status of residence & Responses & $\%$ & B4. Are you married? & Responses & $\%$ \\
\hline Owner & 138 & $34.5 \%$ & Yes & 333 & $83.3 \%$ \\
\hline Family belonging & 128 & $32.0 \%$ & No & 67 & $16.8 \%$ \\
\hline Join residence & 19 & $4.8 \%$ & Total & 400 & $100.0 \%$ \\
\hline Rent & 91 & $22.8 \%$ & & & \\
\hline Others & 24 & $6.0 \%$ & & & \\
\hline Total & 400 & $100.0 \%$ & & & \\
\hline $\begin{array}{l}\text { B5. How many people do } \\
\text { you live with? }\end{array}$ & Responses & $\%$ & $\begin{array}{l}\text { B6. Do you know the } \\
\text { causes and impacts of } \\
\text { coastal flooding? }\end{array}$ & Responses & $\%$ \\
\hline 1-3 people & 119 & $29.8 \%$ & Yes & 292 & $73.0 \%$ \\
\hline 4-6 people & 234 & $58.5 \%$ & No & 108 & $27.0 \%$ \\
\hline 7-9 people & 34 & $8.5 \%$ & Total & 400 & $100.0 \%$ \\
\hline$>9$ people & 13 & $3.3 \%$ & & & \\
\hline Total & 400 & $100.0 \%$ & & & \\
\hline
\end{tabular}




\begin{tabular}{|c|c|c|c|c|c|}
\hline $\begin{array}{l}\text { B7. Which do you think } \\
\text { is the biggest cause of } \\
\text { coastal flooding? }\end{array}$ & Responses & $\%$ & $\begin{array}{l}\text { B8. When does coastal } \\
\text { flooding usually occur? }\end{array}$ & Responses & $\%$ \\
\hline Land subsidence & 44 & $11.0 \%$ & Uncertain & 184 & $46.0 \%$ \\
\hline $\begin{array}{l}\text { Excessive use of } \\
\text { groundwater }\end{array}$ & 10 & $2.5 \%$ & When the rainfall is high & 113 & $28.3 \%$ \\
\hline Sea level rise & 238 & $59.5 \%$ & When the moon is full & 103 & $25.8 \%$ \\
\hline Poor drainage & 65 & $16.3 \%$ & Total & 400 & $100.0 \%$ \\
\hline Waste & 43 & $10.8 \%$ & & & \\
\hline Total & 400 & $100.0 \%$ & & & \\
\hline $\begin{array}{l}\text { B9. How many floods } \\
\text { occur in a month? }\end{array}$ & Responses & $\%$ & $\begin{array}{l}\text { B10. How long will the } \\
\text { floods recede? }\end{array}$ & Responses & $\%$ \\
\hline No occurrence & 111 & $27.8 \%$ & One hour & 167 & $41.8 \%$ \\
\hline $1-3$ times & 256 & $64.0 \%$ & $2-3$ hours & 181 & $45.3 \%$ \\
\hline $4-5$ times & 26 & $6.5 \%$ & $>3$ hours & 52 & $13.0 \%$ \\
\hline$>5$ times & 7 & $1.8 \%$ & Total & 400 & $100.0 \%$ \\
\hline Total & 400 & $100.0 \%$ & & & \\
\hline $\begin{array}{l}\text { B11. What is the depth of } \\
\text { the water during a flood? }\end{array}$ & Responses & $\%$ & $\begin{array}{l}\text { B12. Has the head of } \\
\text { RT/RW in your } \\
\text { neighborhood ever } \\
\text { provided information } \\
\text { about floods? }\end{array}$ & Responses & $\%$ \\
\hline $0-30 \mathrm{~cm}$ & 281 & $70.3 \%$ & Never & 113 & $28.3 \%$ \\
\hline $31-50 \mathrm{~cm}$ & 103 & $25.8 \%$ & Rarely & 151 & $37.8 \%$ \\
\hline$>50 \mathrm{~cm}$ & 16 & $4.0 \%$ & One a time & 68 & $17.0 \%$ \\
\hline \multirow[t]{3}{*}{ Total } & 400 & $100.0 \%$ & Often & 55 & $13.8 \%$ \\
\hline & & & Always & 13 & $3.3 \%$ \\
\hline & & & Total & 400 & $100.0 \%$ \\
\hline $\begin{array}{l}\text { B13. Do you participate } \\
\text { in any organizations } \\
\text { related to flood disasters? }\end{array}$ & Responses & $\%$ & $\begin{array}{l}\text { B14. What is the } \\
\text { ownership status of your } \\
\text { house? }\end{array}$ & Responses & $\%$ \\
\hline Yes & 81 & $20.3 \%$ & Government assistance & 12 & $3.0 \%$ \\
\hline No & 319 & $79.8 \%$ & Rent & 112 & $28.0 \%$ \\
\hline \multirow[t]{2}{*}{ Total } & 400 & $100.0 \%$ & Own property & 276 & $69.0 \%$ \\
\hline & & & Total & 400 & $100.0 \%$ \\
\hline $\begin{array}{l}\text { B15. What kind of } \\
\text { house? }\end{array}$ & Responses & $\%$ & $\begin{array}{l}\text { B16. How large the } \\
\text { building you live in? }\end{array}$ & Responses & $\%$ \\
\hline Not permanent & 44 & $11.0 \%$ & $<21 \mathrm{~m}^{2}$ & 55 & $13.8 \%$ \\
\hline Semi-permanent & 116 & $29.0 \%$ & $21 \mathrm{~m}^{2}$ & 89 & $22.3 \%$ \\
\hline Permanent & 240 & $60.0 \%$ & $36 \mathrm{~m}^{2}$ & 113 & $28.3 \%$ \\
\hline \multirow[t]{3}{*}{ Total } & 400 & $100.0 \%$ & $45 \mathrm{~m}^{2}$ & 68 & $17.0 \%$ \\
\hline & & & $>45 \mathrm{~m}^{2}$ & 75 & $18.8 \%$ \\
\hline & & & Total & 400 & $100.0 \%$ \\
\hline
\end{tabular}




\begin{tabular}{|c|c|c|c|c|c|}
\hline $\begin{array}{l}\text { B17. How old is the } \\
\text { building you live in? }\end{array}$ & Responses & $\%$ & $\begin{array}{l}\text { B18. How many floors } \\
\text { are in the building you } \\
\text { live in? }\end{array}$ & Responses & $\%$ \\
\hline$<10$ years & 81 & $20.3 \%$ & One storey & 258 & $64.5 \%$ \\
\hline 10-20 years & 164 & $41.0 \%$ & Two storey & 124 & $31.0 \%$ \\
\hline$>20$ years & 155 & $38.8 \%$ & High rise & 18 & $4.5 \%$ \\
\hline Total & 400 & $100.0 \%$ & Total & 400 & $100.0 \%$ \\
\hline $\begin{array}{l}\text { B19. What house } \\
\text { reconstruction efforts } \\
\text { have you done in } \\
\text { response to the flood? }\end{array}$ & Responses & $\%$ & $\begin{array}{l}\text { B20. What impact did } \\
\text { you feel when you were } \\
\text { hit by the flood? }\end{array}$ & Responses & $\%$ \\
\hline Raise the ground floor & 136 & $34.0 \%$ & $\begin{array}{c}\text { Properties damage } \\
\text { (houses, vehicles, } \\
\text { household appliances) }\end{array}$ & 176 & $44.0 \%$ \\
\hline Increase the storey & 30 & $7.5 \%$ & $\begin{array}{c}\text { Cut off access to utilities } \\
\text { (roads, clean water, } \\
\text { electricity, } \\
\text { telecommunications) }\end{array}$ & 85 & $21.3 \%$ \\
\hline $\begin{array}{l}\text { Build embankments to } \\
\text { withstand the water }\end{array}$ & 68 & $17.0 \%$ & Casualties/injuries & 4 & $1.0 \%$ \\
\hline $\begin{array}{l}\text { Build the drainage in front } \\
\text { of the house }\end{array}$ & 50 & $12.5 \%$ & $\begin{array}{c}\text { Various kinds of diseases } \\
\text { arise }\end{array}$ & 111 & $27.8 \%$ \\
\hline Nothing & 116 & $29.0 \%$ & $\begin{array}{l}\text { Reduced income due to } \\
\text { inability to work }\end{array}$ & 24 & $6.0 \%$ \\
\hline Total & 400 & $100.0 \%$ & Total & 400 & $100.0 \%$ \\
\hline $\begin{array}{l}\text { B21. What is your reason } \\
\text { for staying in your } \\
\text { current location? }\end{array}$ & Responses & $\%$ & $\begin{array}{l}\text { B22. What is the } \\
\text { condition of the drainage } \\
\text { in your neighborhood? }\end{array}$ & Responses & $\%$ \\
\hline Close to workplaces & 107 & $26.8 \%$ & Flows & 218 & $54.5 \%$ \\
\hline Close to family & 64 & $16.0 \%$ & Clogged up (mud, waste) & 115 & $28.8 \%$ \\
\hline $\begin{array}{l}\text { Have been living in the } \\
\text { place for a long time }\end{array}$ & 229 & $57.3 \%$ & Puddle & 67 & $16.8 \%$ \\
\hline Total & 400 & $100.0 \%$ & Total & 400 & $100.0 \%$ \\
\hline $\begin{array}{l}\text { B23. What kind of flood } \\
\text { warning system is in } \\
\text { your neighborhood? }\end{array}$ & Responses & $\%$ & $\begin{array}{l}\text { B24. What sources of } \\
\text { information do you } \\
\text { usually get regarding } \\
\text { flood events? (including } \\
\text { flood predictions) }\end{array}$ & Responses & $\%$ \\
\hline $\begin{array}{l}\text { Traditional (Kentongan, } \\
\text { an announcement from } \\
\text { the mosque) }\end{array}$ & 81 & $20.3 \%$ & See natural signs & 115 & $28.8 \%$ \\
\hline $\begin{array}{l}\text { Flood warning system } \\
\text { through technology } \\
\text { (internet) }\end{array}$ & 69 & $17.3 \%$ & $\begin{array}{l}\text { Information from } \\
\text { neighbors / family }\end{array}$ & 51 & $12.8 \%$ \\
\hline There is no system & 250 & $62.5 \%$ & $\begin{array}{l}\text { Information from local } \\
\text { government officials }\end{array}$ & 58 & $14.5 \%$ \\
\hline Total & 400 & $100.0 \%$ & $\begin{array}{c}\text { Information from } \\
\text { newpaper/TV / Internet }\end{array}$ & 176 & $44.0 \%$ \\
\hline & & & Total & 400 & $100.0 \%$ \\
\hline
\end{tabular}




\begin{tabular}{|c|c|c|c|c|c|}
\hline $\begin{array}{l}\text { B25. Where do you } \\
\text { usually evacuate if there } \\
\text { is a flood? }\end{array}$ & Responses & $\%$ & $\begin{array}{l}\text { B26. What transportaion } \\
\text { do you use to evacuate } \\
\text { during an emergency? }\end{array}$ & Responses & $\%$ \\
\hline House of relatives & 70 & $17.5 \%$ & Wooden boat & 29 & $7.3 \%$ \\
\hline $\begin{array}{l}\text { Disaster posts provided by } \\
\text { the government }\end{array}$ & 126 & $31.5 \%$ & Inflatable boat & 157 & $39.3 \%$ \\
\hline Open field/tent & 19 & $4.8 \%$ & Car & 19 & $4.8 \%$ \\
\hline Hotel & 3 & $0.8 \%$ & Motorcycle & 195 & $48.8 \%$ \\
\hline Stay at home & 182 & $45.5 \%$ & Total & 400 & $100.0 \%$ \\
\hline Total & 400 & $100.0 \%$ & & & \\
\hline
\end{tabular}

B27. What types of fund allocations do you have in response to the flood

Responses disaster?

\begin{tabular}{|c|c|c|c|c|c|}
\hline Savings & 87 & $21.8 \%$ & $\begin{array}{l}\text { Yes, it is sufficient during } \\
\text { the flood }\end{array}$ & 56 & $14.0 \%$ \\
\hline Life insurance & 20 & $5.0 \%$ & $\begin{array}{l}\text { Yes, but not quite } \\
\text { sufficient }\end{array}$ & 140 & $35.0 \%$ \\
\hline Property insurance & 7 & $1.8 \%$ & Nothing helps & 204 & $51.0 \%$ \\
\hline Bank loans & 4 & $1.0 \%$ & Total & 400 & $100.0 \%$ \\
\hline Inveestment & 6 & $1.5 \%$ & & & \\
\hline No fund allocations & 276 & $69.0 \%$ & & & \\
\hline Total & 400 & $100.0 \%$ & & & \\
\hline $\begin{array}{l}\text { B29. Who helped you } \\
\text { during and after the } \\
\text { flood? }\end{array}$ & Responses & $\%$ & $\begin{array}{c}\text { B30. What assistance was } \\
\text { provided? }\end{array}$ & Responses & $\%$ \\
\hline Government & 170 & $42.5 \%$ & Food supply & 260 & $65.0 \%$ \\
\hline $\begin{array}{c}\text { Non-governmental } \\
\text { organization }\end{array}$ & 47 & $11.8 \%$ & Clothes and blankets & 68 & $17.0 \%$ \\
\hline Relatives & 163 & $40.8 \%$ & Medical examination & 40 & $10.0 \%$ \\
\hline Private parties & 20 & $5.0 \%$ & Home appliance & 5 & $1.3 \%$ \\
\hline \multirow[t]{2}{*}{ Total } & 400 & $100.0 \%$ & Money & 27 & $6.8 \%$ \\
\hline & & & Total & 400 & $100.0 \%$ \\
\hline $\begin{array}{l}\text { B31. How much money } \\
\text { did you spend to recover } \\
\text { from the flood? }\end{array}$ & Responses & $\%$ & $\begin{array}{l}\text { B32. How much money } \\
\text { did you save in a month? }\end{array}$ & Responses & $\%$ \\
\hline$<\operatorname{Rp} 100,000$ & 102 & $25.5 \%$ & Nothing & 185 & $46.3 \%$ \\
\hline Rp 100,000-Rp 500,000 & 100 & $25.0 \%$ & $<\operatorname{Rp} 250,0000$ & 73 & $18.3 \%$ \\
\hline $\operatorname{Rp} 500,000-\operatorname{Rp} 1,000,000$ & 95 & $23.8 \%$ & Rp 250,000-Rp 500,000 & 73 & $18.3 \%$ \\
\hline$>\operatorname{Rp} 1,000,000$ & 103 & $25.8 \%$ & Rp 500,000-Rp 1,000,000 & 41 & $10.3 \%$ \\
\hline \multirow[t]{2}{*}{ Total } & 400 & $100.0 \%$ & $>\operatorname{Rp} 1,000,000$ & 28 & $7.0 \%$ \\
\hline & & & Total & 400 & $100.0 \%$ \\
\hline
\end{tabular}
flood, did you have
financial assistance?

Responses $\quad \%$

$\%$ flood, did you have Responses $\%$

Yes, it is sufficient during

B28. During and after the 


\begin{tabular}{ccc}
\hline B33. How much money did you spend in a month? & Responses & \% \\
\hline$<\operatorname{Rp} 500,000$ & 34 & $8.5 \%$ \\
\hline $\operatorname{Rp~} 500,000-\operatorname{Rp~} 1,000,000$ & 32 & $8.0 \%$ \\
\hline $\operatorname{Rp~} 1,000,000-\operatorname{Rp} 1500,000$ & 49 & $12.3 \%$ \\
\hline $\operatorname{Rp~} 1,500,000-\operatorname{Rp~} 2,000,000$ & 106 & $26.5 \%$ \\
\hline$>\operatorname{Rp} 2,000,000$ & 179 & $44.8 \%$ \\
\hline Total & $\mathbf{4 0 0}$ & $\mathbf{1 0 0 . 0} \%$ \\
\hline
\end{tabular}

Source: Author's own calculations.

\section{References}

1. National Oceanic and Atmospheric Administration. Coastal Services Center, Coastal Inundation Toolkit. Available online: http:/ / www.csc.noaa.gov (accessed on 27 April 2016).

2. Jonkman, S.N.; Dawson, R.J. Issues and Challenges in Flood Risk Management-Editorial for Special Issue on Flood Risk Management. Water 2012, 4, 785-792. [CrossRef]

3. Chaussard, E.; Amelung, F.; Abidin, H.; Hong, S.H. Sinking Cities in Indonesia: ALOS PALSAR Detects Rapid Subsidence Due to Groundwater and Gas Extraction. Remote Sens. Environ. 2013, 128, 150-161. [CrossRef]

4. Farhan, A.R.; Lim, S. Integrated Coastal Zone Management Towards Indonesia Global Ocean Observing System (INA-GOOS): Review and Recommendation. Ocean. Coast. Manag. 2010, 53, 421-427. [CrossRef]

5. Setyawan, A.; Fukuda, Y.; Nishijima, J.; Kazama, T. Detecting Land Subsidence Using Gravity Method in Jakarta and Bandung Area, Indonesia. Procedia Environ. Sci. 2015, 23, 17-26. [CrossRef]

6. Bappenas. Laporan Perkiraan Kerusakan dan Kerugian Pasca Bencana Banjir Awal Februari 2007 di Wilayah JABODETABEK (Jakarta, Bogor, Depok, Tangerang, dan Bekasi); BAPPENAS Jakarta: Jakarta, Indonesia, 2007.

7. Budiyono, Y.; Aerts, J.C.J.H.; Tollenaar, D.; Ward, P.J. River flood risk in Jakarta under scenarios of future change. Nat. Hazards Earth Syst. Sci. 2016, 16, 757-774. [CrossRef]

8. Sagala, S.; Lassa, J.; Yasaditama, H.; Hudalah, D. The Evolution of Risk and Vulnerability in Greater Jakarta: Contesting Government Policy in Dealing with a Megacity's Exposure to Flooding; An Academic Response to Jakarta Floods in January 2013; Working Paper No.2; Institute of Resource Governance and Social Change: Nusa Tenggara, Indonesia, 2013; Available online: http:/ /irgsc.org/pubs/wp/IRGSCWP002jakartaflood.pdf (accessed on 17 December 2020).

9. Doong, D.-J.; Chuang, L.; Wu, L.-C.; Fan, Y.-M.; Kao, C.; Wang, J.-H. Development of an operational coastal flooding early warning system. Nat. Hazards Earth Syst. Sci. 2012, 12, 379-390. [CrossRef]

10. World Meteorological Organization (WMO). Coastal Flooding Forecast Strengthened in Indonesia. Available online: https:/ / public.wmo.int/en/media/news/coastal-flooding-forecast-strengthened-indonesia (accessed on 17 December 2020).

11. Fakhruddin, S. Risk Communications for Coastal Inundation Forecasting to the Community. J. Psychol. Psychother. 2015, 5. [CrossRef]

12. Perera, D.; Agnihotri, J.; Seidou, O.; Djalante, R. Identifying societal challenges in flood early warning systems. Int. J. Disaster Risk Reduct. 2020, 51, 101794. [CrossRef]

13. The International Federation of Red Cross and Red Crescent Societies (IFRC). World Disaster Report 2009, Focus on Early Warning, Early Action; IFRC: Paris, France, 2009.

14. Lopez, G.M.; Di Baldassarre, G.; Seibert, J. Impact of social preparedness on flood early warning systems. Water Resour. Res. 2017, 53. [CrossRef]

15. Sattele, M.; Brundl, M.; Straub, D. Reliability and effectiveness of early warning systems for natural hazards: Concept and application to debris flow warning. Reliab. Eng. Syst. Saf. 2015, 142, 192-202. [CrossRef]

16. Rahman, M.M.; Goel, N.K.; Arya, D.S. Study of early flood warning dissemination system in Bangladesh. J. Flood Risk Manag. 2013, 6, 290-301. [CrossRef]

17. REACH. A Study on Knowledge, Attitudes \& Practices for Disaster Risk Reduction in Northern Rakhine State. Published August 2015. Available online: https://themimu.info/sites/themimu.info/files/documents/Assessment_Report_KAP_for_DRR_in_ Northern_Rakhine_REACH_Aug2015.pdf (accessed on 17 December 2020).

18. Gaillard, J.C. Vulnerability, capacity, and resilience: Perspectives for climate and development policy. J. Int. Dev. 2010, 467, 912-913. [CrossRef]

19. Simarmata, H.A. Phenomenology in Adaptation Planning; Springer: Singapore, 2018. [CrossRef]

20. Kim, Y.-C.; Kang, J. Communication, neighbourhood belonging and household hurricane preparedness. Disasters 2010, 34, 470-488. [CrossRef] [PubMed]

21. Mulyana, D. Komunikasi Suatu Pengantar; Rosda Karya: Bandung, Indonesia, 2001.

22. Slovic, P.; Fischhoff, B.; Lichtenstein, S.; Roe, F. Perceived Risk: Psychological Factors and Social Implications [and Discussion]. Proc. R. Soc. Lond. Ser. A Math. Phys. Sci. 1981, 376, 17-34. Available online: http://www.jstor.org/stable/2397115 (accessed on 17 December 2020). 
23. Siegrist, M.; Gutscher, H. Natural hazards and motivation for mitigation behavior: People cannot predict the affect evoked by a severe flood. Risk Anal. 2008, 28, 771-778. [CrossRef]

24. Bubeck, P.; Botzen, W.J.W.; Aerts, J.C.J.H. A review of risk perceptions and other factors that influence flood mitigation behavior. Risk Anal. 2012, 32, 1481-1495. [CrossRef]

25. Becker, G.; Aerts, J.; Huitema, D. Influence of flood risk perception. J. Flood Risk Manag. 2014, 7, 16-30. [CrossRef]

26. Grothmann, T.; Reusswig, F. People at Risk of Flooding: Why Some Residents Take Precautionary Action While Others Do Not. Nat. Hazards 2006, 38, 101-120. [CrossRef]

27. Lechowska, E. What determines flood risk perception? A review of factors of flood risk perception and relations between its basic elements. Nat. Hazards 2018, 94, 1341-1366. [CrossRef]

28. Kellens, W.; Zaalberg, R.; Neutens, T.; Vanneuville, W.; De Maeyer, P. An analysis of the public perception of flood risk on the Belgian coast. Risk Anal. 2011, 31, 1055-1068. [CrossRef]

29. Kaiser, F.G.; Oerke, B.; Bogner, F.X. Behavior-based environmental attitude: Development of an Instrument for Adolescents. J. Environ. Psychol. 2007, 27, 242-251. [CrossRef]

30. Ryan, T.P. Sample Size Determination and Power; John Wiley and Sons: Hoboken, NJ, USA, 2013.

31. Wang, R.; Huston, S.; Li, Y.; Ma, H.; Peng, Y.; Ding, L. Temporal Stability of Groundwater Depth in the Contemporary Yellow River Delta, Eastern China. Sustainability 2018, 10, 2224. [CrossRef]

32. De Silva, M.M.G.T.; Kawasaki, A. A local-scale analysis to understand differences in socioeconomic factors affecting economic loss due to floods among different communities. Int. J. Disaster Risk Reduct. 2020, 47, 101526. [CrossRef]

33. Prihanto, Y.; Koestoer, R.H.; Sutjiningsih, D.; Darmajanti, L. Rain harvesting patterns for a dynamic secondary city: A case study of Semarang City. IOP Conf. Ser. Earth Environ. Sci. 2018, 202, 012065. [CrossRef]

34. Lo, A.Y. The role of social norms in climate adaptation: Mediating risk perception and flood insurance purchase. Glob. Environ. Chang. 2013, 23, 1249-1257. [CrossRef]

35. Terpstra, T. Emotions, Trust, and Perceived Risk: Affective and Cognitive Routes to Flood Preparedness Behavior. Risk Anal. 2011, 31, 1658-1675. [CrossRef]

36. Myatt, L.B.; Scrimshaw, M.; Lester, J. Public Perceptions and Attitudes Towards a Current Managed Realignment Scheme: Brancaster West Marsh, North Norfolk, U.K. J. Coast. Res. 2003, 19, 278-286. Available online: www.jstor.org/stable/4299169 (accessed on 17 December 2020).

37. Huang, J. Affect Path to Flood Protective Coping Behaviors Using SEM Based on a Survey in Shenzhen, China. Int. J. Environ. Res. Public Health 2020, 17, 940. [CrossRef]

38. Ajibade, I.; Armah, F.A.; Kuuire, V.Z.; Luginaah, I.; McBean, G.; Tenkorang, E.Y. Assessing the Bio-psychosocial Correlates of Flood Impacts in Coastal Sreas of Lagos, Nigeria. J. Environ. Plan. Manag. 2015, 58, 445-463. [CrossRef]

39. Ngo, C.C.; Poortvliet, P.M.; Feindt, P.H. Drivers of flood and climate change risk perceptions and intention to adapt: An explorative survey in coastal and delta Vietnam. J. Risk Res. 2020, 23, 424-446. [CrossRef]

40. Rahmayati, Y.; Parnell, D.; Himmayani, V. Understanding Community-Led Resilience: The Jakarta Floods Experience. Aust. J. Emerg. Manag. 2017, 32, 58. Available online: https://knowledge.aidr.org.au/resources/ajem-oct-2017-understandingcommunity-led-resilience-the-jakarta-floods-experience/ (accessed on 17 December 2020). 